\title{
E-Management System of Kirkuk University Based on Distributed Database
}

\author{
Banaz Anwer Qader \\ bnazanwr@gmail.com
}

Recived : 517/2017
Kamal Hasan Jihad

University of Kirkuk / College of Science

kamalscience85@gmail.com

yelhan1982@gmail.com

\begin{abstract}
.
This research includes an analytical study of the administrative and scientific work in departments, branchs and units of the Kirkuk University Presidency. It aims to convert the traditional routine work to the electronic work at the university by applying E-Management technique as one of the required modern logical solutions most commonly used to facilitate the difficulty of managing the vast amount of documents and delaying workflow that facing most institutions and organizations. In view of the increasing and urgent need for the use of E-Management systems throughout all the departments of the university presidency, the Electronic Distributed Kirkuk University Management System (E-DKUMS) is designed by using of Distributed Databases (DDB) technique, as well as using of electronic network infrastructure (LAN) that connects all the university configurations. The results of system implementation demonstrated that it is distinguished with high performance and speed, very high reliability and security, as well as very few employment cost. Test and evaluation results proved the ability of the system to facilitate the progress of managerial functions, reduce the time and effort, and capability of restructuring the administrative structure because of its excellence with flexibility in the creation and deletion departments, branches, and units for the system; in addition to easily troubleshot and fast execution.
\end{abstract}

Key Words. E-management, DDB, DDBMS, E-government, Kirkuk University, ICT.

\section{Introduction.}

It is worth mentioning, that Egovernment is simply a use of the technology to improve the access to and receipt of government services to benefit citizens, business partners and employees. It has the capability to create a new style of public services, where all public organizations receipt modernistic, integral and flexible services for their citizens [1].
Therefore, the e-Government services to be available in our foundation, we need basically to put the suitable basis for that. In this case we introduce this study as a necessary work for that. Thus we can see nowadays, apparently computer systems expand and develop rapidly in our life; it can allocate and solve our problem more quickly than any other ordinary systems and even more precise. So that it will be a good thought and good initiative to computerize any project [2]. Distributed computing is one of the most recent and important developments in the computing era [3]. 
Beside that the electronic management is a form of the contemporary approaches that seek to convert the traditionally institutions to electronic institutions using information technology (IT) in the managing all its transactions and managerial functions [4]. The implementing of E-Management will be a true challenge for the leaders of the enterprises at the present time. In addition, the E-Management implies a development per staff of the management culture within an organization. In practice, it is absolutely necessary to use various information and communication technologies (ICT) to implement the E-Management like distributed database technique and networking techniques which represent one of the most common used techniques in the EManagement aspects [4]. A DDB is a database in which parts of the database (DB) are stored on multiple computers within a network. Distributed database gives users the possibility of access to the part of the database at their locations where they can access the data related to their tasks without overlapping with the data related to works of others [5].

The internet, intranet, and extranet also increase in computer use and development of managerial concepts. The ICT has entered different aspects of administrative functions, as there is not any institution freed from databases for various managerial functions. The information technology (IT) has become the component of modernistic institutions and without it the institution cannot keep working. Therefore, the update of managerial functions became the most important characteristic nowadays, which should be dealt with it efficiently. As a result, these changes have converted the administrative work from conventional methods that depend on papers and business routine to electronic methods in business administration [4].
This study aims to apply the EManagement technology for being one of the reasonable solutions for the documents multitude that most of the organizations and institutions are confronted with.

The study target is to design and implement an E-management system that transforms a classic management system into a management system that is distinguished by availability, performance, capability, changeable solutions, security

Therefore, the E-DKUMS is designed and implemented for managing the administrative work in Kirkuk University presidency institution. Where, the studying and analyzing of the administrative work flow which represented by the managerial functions (archiving documents, sending outgoing documents, receiving incoming documents, printing, signing up, marginalization) in the Kirkuk University presidency institution has proved that the need to use papers decreased somewhat, and manager can do managerial activities at anytime and anywhere more efficiently than ago. So that, an E-management is the most common aspect in the management area, depending on the use of the communication networks and internet in the completion of the managerial functions electronically.

This study starts with analyzing the matter and detecting the requirements of the system; then designing the system and eventually ends with implementing and evaluating of the system.

\section{Analysis and Design of E-DKUMS}

In this section, the main steps of analyzing and designing E-DKUMS will be described and explained in detail. 


\section{2-1 Requirements Analysis of E-DKUMS:}

In respect of design any system, it is necessary to study the system and analyze its requirements. System requirements analysis is a very important stage to create a complete idea about the system that should be designed. In this research, a universal study have been made about traditional ordinary managerial system that related the administrative work flow of the Kirkuk University presidency, and also the proposed requirements have been analyzed which includes "hardware requirements" and "software requirements" for designing an E-Management system for the Kirkuk University presidency named EDKUMS using distributed database technique.

The hardware requirements of E-DKUMS comprises the devices that used in the design and implementation of the system, where it is needed to use a Server and the client computers spread over the departments of Kirkuk University presidency, and it is also needed to create a local area network (LAN) to connect the Server with all the computers within the institution departments using LAN topologies such as mobile Adhoc Network and Ethernet LAN topology because these are easy to management and implementation; and the cost of their possession is relatively lower than other technologies when trying to connect many computers together.

The required and used Server Software for implementing E-DKUMS include Linux (SentOS 7) to be installed as server operating system because it is friendly and easy in use, XAMPP Server software, and recent versions of Microsoft office. It is used the DBMS (MYSQL) for designing the DB structure. It is also used $\mathrm{C \#}$ programming language and PHP for designing the system forms and structure. The Client Software that the Clients have needed to open and enter the E-DKUMS are recent versions of operating system like windows7 or newer versions, new versions of Microsoft office, modern versions of internet browsers such as Firefox, Microsoft Internet Explorer, Google chrome and others so as to support the use of the system and perform different managerial functions.

\section{2-2 The Design of E-DKUMS}

After analyzing system requirements and collecting information of the traditional management work from the Kirkuk University presidency, it is necessary to move to the design stage to start designing the system including its structure design and database design. The design stage is partitioned into two sub stages which are logical design and physical design.

\section{A. Logical Design:}

The logical design which includes database design displays the attributes that the EDKUMS database consists of, as well as the logical relations among DB attributes. For EDKUMS, it is used Top-down design that begins by appointing the data sets, and then defining the data elements for each of those sets. This operation includes the appointment of variant types of entities and the attributes definition of all DB entities. As a result of logical design, the DB design schema shown in figure (1) illustrates entities' attributes and the relationship among these entities. The designed DB consists of (17) entities. Details about E-DKUMS database entities are explained in table (1). 


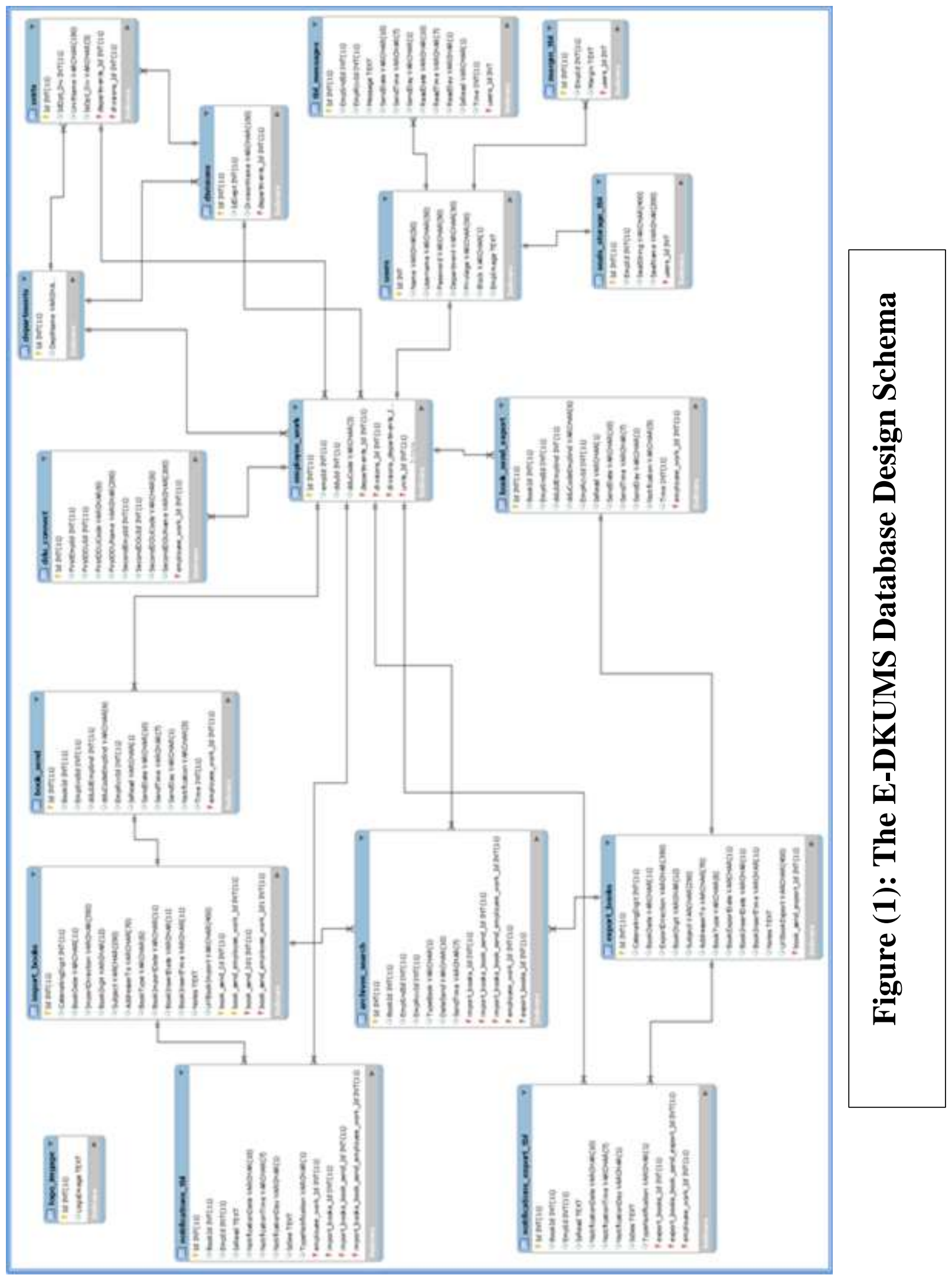


Table (1): Details about E-DKUMS Database Entities

\begin{tabular}{|c|c|c|}
\hline No. & Entity name & Entity functionality \\
\hline 1 & Import_books & It saves all information of incoming documents to the institution. \\
\hline 2 & Export_books & It saves all information of outgoing documents from the institution \\
\hline 3 & Book_send & $\begin{array}{l}\text { It retains all information about resending incoming documents among } \\
\text { institution's departments and their branches and units }\end{array}$ \\
\hline 4 & Book_send_export & $\begin{array}{l}\text { It retains all information about resending outgoing documents among } \\
\text { institution's departments and their branches and units }\end{array}$ \\
\hline 5 & Archives_search & $\begin{array}{l}\text { It retains the information that produced from search operation about } \\
\text { incoming and outgoing documents }\end{array}$ \\
\hline 6 & Notification_tbl & $\begin{array}{l}\text { It contains the information (that appear to the receivers (employees) as a } \\
\text { notification) of sender (manager or responsible employee) name as soon } \\
\text { as he/she sends incoming documents to the employees inside the } \\
\text { institution, or signs up, margins, uploads an addition document on the } \\
\text { previously sent document, document title, and date and time, day, type of } \\
\text { the notification. }\end{array}$ \\
\hline 7 & Notification_export_tbl & $\begin{array}{l}\text { It is similar to the Notification_tbl entity. It keeps the same information, } \\
\text { but for outgoing documents. }\end{array}$ \\
\hline 8 & Units & It includes information of all the institution's units \\
\hline 9 & Divisions & It includes information of all the institution's branches \\
\hline 10 & Departments & It includes information of all the institution's departments \\
\hline 11 & Users & $\begin{array}{c}\text { It includes information of the system users (managers and employees) in } \\
\text { the institution }\end{array}$ \\
\hline 12 & Tbl_messages & $\begin{array}{l}\text { It contains information about sent incoming documents and sent outgoing } \\
\text { documents }\end{array}$ \\
\hline 13 & Margin_tbl & It contains information of employees' marginalization \\
\hline 14 & Seals_storage_tbl & It contains information of employees' signatures \\
\hline 15 & Ddu_connect & $\begin{array}{l}\text { It connects two employees from two different institution's departments } \\
\text { with each other. It allows not only sending and receiving of documents } \\
\text { among the department and its branches and units but also between any } \\
\text { two departments, }\end{array}$ \\
\hline 16 & Employee_work & $\begin{array}{l}\text { It connects the entities (departments, divisions (branches), units) with the } \\
\text { users (employees) entity. }\end{array}$ \\
\hline 17 & Logo_image & It includes background image of major form for entering to the system. \\
\hline
\end{tabular}




\section{B. Physical design:}

Physical design displays general concept of the system structure and its basic

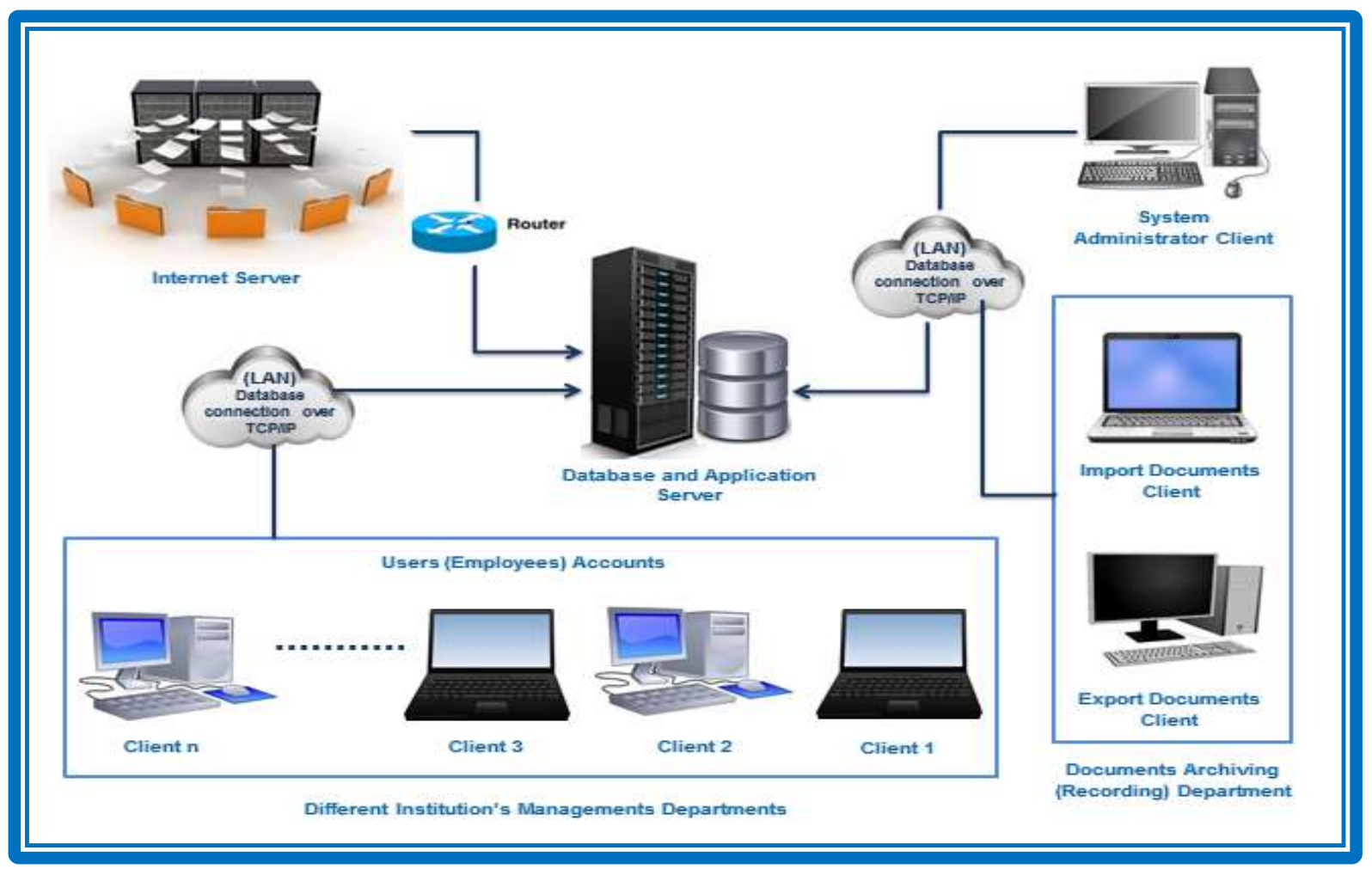

Figure (2): The Architecture of the E-DKUMS

\section{2-3 The Advantages of Design the E-DKUMS}

The traditional work of the Kirkuk University presidency can be converted to an electronic regular work, and its disadvantages can be eliminated by designing the E-DKUMS which provides the following advantages:

1- Decreasing efforts and increasing the productivity by providing electronic connection among the departments.

2- Dependence single systematic electronic system by all the institution's departments, branches, and units to perform functional works instead of dependence multiple various software to perform their managerial work.
3- Unify the archiving of documents by specifying special account for a special

employee for this purpose, and creating special entities (tables) in the DB for recording outgoing and incoming documents.

4- Unify the databases of the institution's departments into one database distributed over the departments, branches, and units of the institution which are connected to the network.

5- Availability of high reliability and high security by providing password and user name to enter the system, in addition to providing a special account for each employee, using fragmentation technique that allows him/her just access to the permitted part of the DB. 


\section{Implementation of the E-DKUMS}

The implementation stage is divided into two sub stages:

\section{3-1 Settings before Implementation}

In this section, the implementation of the proposed design of the E-DKUMS as a local website will be described. First, the implementation process needs building client/server network by connecting the hardware and installing software as explained in section (2-1). Where, performing the following steps is necessary before implementing the E-DKUMS:

a) Installing XAMPP Server software on the server computer, which supports PHP needed for running the system.

b) Using the DBMS (MYSQL) for designing the DB structure shown in figure (1).

c) Using C\# programming language for designing the system forms and structure as demonstrated in section (2-1).

d) The designed E-DKUMS system is installed on the server computer by saving the E-DKUMS complete folder which includes the DB file, installation file, as well as other supported files and programs in the path (C: Program Files $\backslash X A M P P \backslash$ tdocs $\backslash$ system complete folder name).

After preparing the settings, the implementation process done in both server and client sides can be briefly explained as following:

a. Client side: The E-DKUMS can be executed from any client computer in any department, branch, or unit in the Kirkuk University presidency that connected with the E-DKUMS network and has permission from administrator for more security. Clients can access and execute the system by using IP addresses and writing the URL of E-DKUMS (server IP/ E-Management) in the client browser.

b. Server side: In the server computer, E-DKUMS can be accessed by writing the URL (local host/ EManagement), then entering privileged user name and special password of the E-DKUMS which give high security to the system, and press Log In button.

\section{Banaz .A / Kamal .H / Yalmaz .N}

E-DKUMS allows user (employee) to access, display, and manage only the documents which are received and sent by himlher. The fragmentation technique has been used to access just portion of the data that are special of the employee or permitted for him to access it, so as to make the system more secure. Also, replication technique has been used to make copy of DB tables in the server be existed in the client computers that are connected to the server via LAN network.

The E-DKUMS system consists of many major and minor interfaces to execute it easily and to support the institution's manager or users (employees) in the process of institution management and performing managerial functions. The managerial functions of EDKUMS are described as executive levels of hierarchal diagram that illustrated by figure (3).

\section{3-2 The Executive Steps of the E-DKUMS:}

The execution of E-DKUMS can be embedded by six levels with three accounts as follow:

1- Level 1:

After writing the URL of the system in the browser, the main interface of the system will be appeared which requires username and password of the system to log in to the E-DKUMS, as illustrated in level 1 of figure (3).

\section{2- Level 2:}

After logging in to the system, there are three main accounts; each one of them is represented by an interface to help the employee owning an account, so as to perform many different administrative functions, as illustrated in level 2 of figure (3).

\section{3- Level 3 and Level 4:}

a) In the administrator account, the administrator of the system determines the structure of the institution by adding the departments, branches, and units of the institution to the system. The administrator also manages the employees that are working on the system, by insert their information to the system, as well as assigning each employee to his/her special specified account which may be one of the three main accounts referring to in level 2 of figure (3). 
b) In the recording documents account, the archive staffs that have this account insert the incoming documents information to incoming record (import_books) table in the DB, and insert outgoing documents information to outgoing record (export_books) table in the DB. The archive staffs also save the paths of the documents images when uploading the documents images to the server during (recording) archiving process.

c) In the users (employees) account, each employee has this account whether he/she is a manager, responsible employee, or ordinary employee can display the list of outgoing documents that are sent by him/her and display list of incoming documents that received by him/her, for the purpose of reading the details of the document, editing for performing different procedures on the document, or attaching and uploading additional documents to the opened document. In this account, the employee can look for the sent documents by him/her. When each employee sends or repeats sending any document to another one, the document's information is deleted at his/her sit but saved in the (archive_table). The employee can search for the documents by typing their date and type (i.e. incoming or outgoing), then follow the movement of the document among departments themselves and their branches and units.

\section{4- Level 5 and Level 6:}

After entering the employees' information and the information of the institution's departments, branches, and units to system by the system administrator, in this level which represents the minor interfaces of the EDKUMS; the administrator can perform many different functions like:

a) Connecting between each of two employees that belong to two different departments, modifying and changing the employees' information, as well as deleting the information of any particular employee from the system.

b) Modifying and changing the information of institution's departments, branches, and units, and deleting the information of any removed department, branch, and unit from the system.

c) After archiving the incoming and outgoing documents by inserting their information and uploading their images to the system, in this level the archive staffs can manage the archived documents by modifying their information or their images, deleting any unneeded document's information and image; and also ability of reading and sending the document to the intended manager or employee in the intended department. In this level, after the employee that has users account has displayed the list of incoming and outgoing documents that received by him/her; he/she can manage them by performing different processes like adding his/her signature or marginalization to the document, printing it, or downloading it. 
Journal of AL-Qadisiyah for computer science and mathematics $\quad$ Vol.9 $\quad$ No.2 $\quad$ Year 2017 ISSN (Print): 2074 - 0204

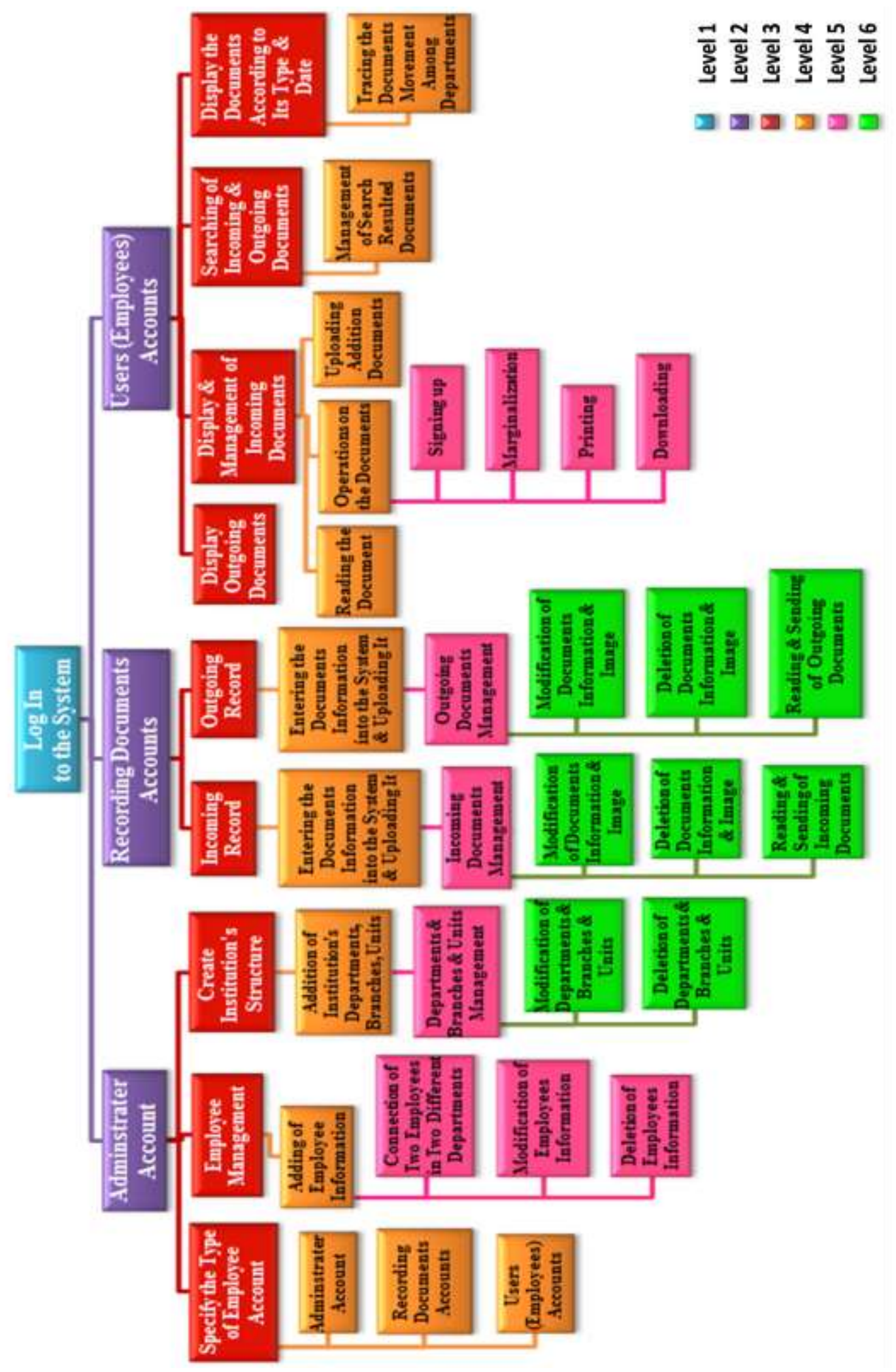

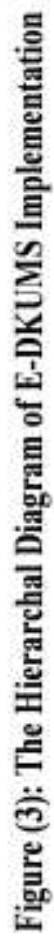




\section{Results and Discussion}

Through implementation and evaluation of the E-DKUMS, it is noticed the necessity of showing the important features that found in the system, so as to be discussed and compared with the ones of traditional management system in the Kirkuk University presidency. It has depended on the questionnaire forms for evaluating both the traditional system and the E-

Table (2): Comparison between the E-DKUMS and the Traditional Prevalent System

\begin{tabular}{|l|c|c|}
\multicolumn{1}{c|}{ parameters } & Traditional system & E-DKUMS \\
\hline $\begin{array}{l}\text { High performance \& } \\
\text { high speed }\end{array}$ & $\times$ & $\checkmark$ \\
\hline Using LAN Network & $\times$ & High \\
\hline Monitoring \& Security & Limited & Possible \\
\hline System Modification & Impossible & $\times$ \\
\hline Employment Effort & $\checkmark$ & $\begin{array}{c}\text { Available: easy to troubleshot and } \\
\text { repair and fast execute }\end{array}$ \\
\hline Serviceability & $\begin{array}{c}\text { Not available: Difficult to resolve } \\
\text { problems and faults }\end{array}$ & $\checkmark$ \\
\hline Apply new software & $\times$ & \multicolumn{2}{c}{. } \\
\hline
\end{tabular}

\section{Conclusions}

Through this study, it is concluded that the EDKUMS can be applied not only in Kirkuk University presidency but also in any other educational institution. The E-DKUMS can also be applied in non-educational institutions like (organizations, companies, stores, factories, industries) due to the possibility of inserting the departments' information of the intended institution into the system as well as flexibility of adding new additional departments of the institution, and deleting unrequired departments from the system. Applying the E-DKUMS for managing any institution electronically requires reconstructing the administrative structure of the institution to be compatible and appropriate with
DKUMS, and applied Weighted Scoring Method (WSM) for

comparing between both of them. WSM is a very useful and easy tool for evaluation, comparison, Prioritize alternatives. Where the decision making matrix (DMM) is used for ranking the important comparison features for both systems, interpreting the results, then choosing the best technological system. The comparison results according to the critical features which have been getting by WSM are illustrated in table (2). 


\section{References}

[1] Bernd W. Wirtz, Peter Daiser, " E-Government | Strategy Process Instruments", text book (1st edition) (September 2015).

[2] Ayad Ghany Ismaeel, Dina Y. Mikhail, "Design of Locally E-Management System for Technical Education Foundation- Erbil", Poly Technic Journal, Vol. 1, No. 1, (October 2011).

[3] Sana J. Alyaseri, "Distributed University Registration Database System Using Oracle 9i”, CCSE, Computer and Information Science, Vol. 3, No. 1, (February 2010).
[4] Hassan. N. Rawash, "Electronic Management's Contribution to the Development of Managerial Functions", Academic Research International Vol. 5, No. 5, ISSN: 2223-9944, (September 2014).

[5] Adrian Runceanu, Ilie Borcoși, Marian Popescu, "ELEARNING AND DISTRIBUTED DATABASES”, Annals of the „Constantin Brancusi” University of Targu Jiu, Engineering Series, Vol. 3, No. 3, (2013).

\section{نظام الإدارة الألكترونية لجامعة كركوك بالاعتماد على قواعد البيانات الموزعة \\ بنــاز انـور قــادر كمال حسن جهاد يلماز نجم الدين طاهر \\ جامعة كركوك / كلية العلوم / قسم الحاسوب}

\footnotetext{
يتضمن البحث الحالي در اسة تحليلية للاعمال الادارية والعلمية في اقسام وشعب ووحدات رئاسة جامعة كركوك. ويهدف الى تحويل العمل التقليدي الروتيني الىى عمل الكتروني في الجامعة وذلك بتطبيق تقنية الادارة الالكترونية كونها احدى الحلول المنطقية الحديثة المطلوبة التي تواكب متطلبات العصر والاكثر شيوعا لتسهيل صعوبة ادارة الكم الهائل من الوثائق والكتب الادارية وتأخير سير العمل التي تواجه معظم المؤسسات و المنظمات. ونظر آ للحاجة المنز ايدة والملحة على استخدام نظم الإدارة الإلكترونية في كافة اقسام رئاسة الجامعة، تم تصميم نظام إدارة جامعة كركوك ولك الإلكترونية الموزعة (E-DKUMS) باستخدام تقنية قو اعد البيانات الموزعة ، فضلا عن استخدام البنية التحتية الإكترونية الثبكية (LAN) الذي يربط الجامعة بكافة تثكيلاتها. توصلت النتائج التطبيقية لهذا النظام الى انه يتميز باداء وسر عة عاليين، امنية ووثوقية عالية جدا، فضلا عن كلفة توظيفية قليلة جدا. اثبتت نتائج الاختبار و التقييم الى قدرة النظام على تسهيل سير الوظائف الادارية، تقليل الوقت و الجهد، وقابليته على اعادة تشكيل الهيكلية الادارية بسبب تميزه بالمرونة في استحداث وحذف الاقسام و الثعب و الوحدات لهذا لنظام بالاضافة الى سهولة معالجة المشاكل و الاخطاء وسر عة التنفيذ.
} 